\title{
The Influence of the Credit Channeling and Utilization of Assets against the Adequacy of Capital at PT. Bank Branch North Sumatra Medan Iskandar Muda
}

\author{
Novien Rialdy ${ }^{1}$ and Laster Jujanwar Bancin ${ }^{2}$ \\ ${ }^{1}$ University of Muslim North Sumatera, Indonesia, e-mail: novienrialdy@umsu.ac.id \\ ${ }^{2}$ University of Muslim North Sumatera, Indonesia
}

\begin{abstract}
As for formulation problems in the research is any influence of utilization of active in credit channeling special and simultaneous concerning capital adequacy at PT. Bank of not Sumatra Branch of Iskandar Muda Medan. In the study used techniques of data collection studies, that documentation related to the problem or research data, as a number of customers credits, financial statements, and others, while the data analysis techniques used multiple regression analysis methods. Based on the results of the analysis can be concluded that test hypothesis with t-test is known for assets value utilization variable to arithmetic 1,843t tabel 2.042 then Ho accepted, and Ha rejected and can be concluded that asset utilization variable does not influence significantly to capital adequacy. In addition, based on testing the hypothesis with $F$ test is known to value of $F$ arithmetic of 16,433 and the value of $\mathrm{F}$ table is 4,42 and the results indicate that $\mathrm{F}$ arithmetic $>\mathrm{F}$ table, that means together with the variable credit distribution and utilization of assets in this study have a significant effect on capital adequacy. In addition, testing the coefficient of determination by using the summary, model is known to the effect of the free variables (credit distribution and asset utilization) to the dependent $\mathrm{t}$ variable (capital adequacy) is $0,499(49,9 \%)$ while the remaining $50,1 \%$ is influenced by other variables not examined in the study.

Keywords: credit disbursement, utilization of active and capital adequacy.
\end{abstract}

\section{Introduction}

Public trust in saving funds in the bank is influenced by the information obtained about the quality and performance of the bank concerned. Banks must be able to maintain customer trust by having sufficient capital for daily operational activities. If a bank has sufficient capital, the bank has sufficient financial resources to guard against potential losses.

Capital in this study is represented by the Capital Adequacy Ratio (CAR). The greater the CAR, the greater the opportunity for banks to generate profits because, with large capital, bank management is very free to place funds into profitable investment activities. CAR is a capital requirement, namely the ratio of the minimum ratio between risk capital and assets that contain risks. A high CAR also shows that the bank is more stable due to stable public trust because CAR is linked to the level of bank risk. The smaller the risk of a bank, the greater the profits obtained by the bank. The high capital ratio can protect customers, which can increase public confidence in banks so that profitability can increase.

In general, banks in Indonesia face problems related to the number of non-performing loans, liquidity, namely the problem of high mobility of public funds in lending so banks must stimulate such highinterest rates so that public funds are collected and capital problems.

The increase in the credit rate is expected to increase the profitability of banking companies. With the provision of credit to the public, it is expected that the economy can be improved, which is very important for the smooth return of credit from debtors. It is known that if the smooth return of credit is hampered, it will also have an adverse impact on banks which can cause bad credit. 
Research related to lending is carried out by Cyndi Adelya and Hotma Jafar (2009) explaining that lending is said to be successful in a bank if the amount of ceiling given is in accordance with the number of returns from debtors. This explains that the credit channeled by a bank to the public is said to run smoothly if there is no bad credit. In addition, Winda Harahap (2015) also conducted research by concluding that lending can run smoothly if the bank pays attention to the procedure of lending well and fulfills the conditions of credit distribution which includes Character, Capacity, Capital, Collateral, Condition of Economy, Constraint, Covering and also implementing methods analysis of 7 P (Personality, Party, Purpose, Prospect, Payment, Profitability, Protection) well.

One phenomenon that becomes an obstacle in operations at PT. North Sumatra Branch Iskandar Muda Branch in connection with the distribution of credit in the utilization of assets, namely the occurrence of bad loans that can cause losses for PT. The North Sumatra Bank Iskandar Muda Branch, therefore, the bank must conduct various ways of selecting credit applications by paying attention to and implementing supervision of loan disbursement properly and fulfilling the terms of credit distribution. But in its implementation, it still shows a phenomenon where the procedure of credit distribution is still not going well, this can be seen from the occurrence of bad credit that really needs special attention from the bank because the amount is quite large.

Based on the description above, it is known the importance of lending and asset utilization to the adequacy of capital at PT. North Sumatra Bank Branch Iskandar Muda, then in this preparation the authors choose the title of the study as follows: "The Effect of Credit Distribution and Utilization of Assets on The adequacy of capital at PT. North Sumatra Bank Branch Iskandar Muda Medan.

The definition of capital according to Siamat $(2009$, p. 45$)$ the capital of a bank is funds invested by the owner to establish a business under the regulation. One important factor to a business development and risk management is capital. A bank's performance is judged by its capital amount. The indicator used to measure the adequacy of capital of a bank is the Capital Adequacy Ratio (CAR). Capital Adequacy Ratio (CAR) is the ratio of the bank's own capital to the available capital requirements after calculating the margin risk of risk assets (RWA) (Siamat, 2009, p. 48).

According to the Bank Indonesia Circular Letter No.12 / 11 / DPNP dated March 31, 2010, the CAR ratio can be formulated as a comparison between bank capital and risk-weighted assets. Basically, Capital Adequacy Ratio (CAR) is the ratio of capital (core capital and complementary capital) to Risk Weighted Assets (RWA) which is adjusted to the regulations set by Bank Indonesia which is $8 \%$. RWA is the total value of each bank asset after multiplying by each risk weight of the asset.

Working capital is essentially a continuous amount that must exist in sustaining the bridging business enterprise between the time of expenditure to obtain materials or services, and the time the company receives (Kamarudin Ahmad, 2006, p. 5), but in addition the excess working capital is also will have a negative impact on company profits. According to Weston and Brigham (2014, p. 424) capital is a factor of production as well as other factors, this capital contains costs. In addition, silent funds should have the opportunity to be turned into larger funds. It can be imagined if working capital is not in sufficient condition, the profit of a company will also be affected.

Furthermore, Abdullah (2012, p. 49), classifying several factors that affect CAR, include:

- The level of quality of the management of the bank concerned

- The level of liquidity it has

- The quality level of assets

- Deposit structure

- The level of quality of the system and procedures

- The level of quality and character of shareholders

- Capacity to meet long-term and short-term needs

- History of capital fertilization and the rules of profit sharing obtained 
According to Weston and Brigham (2014, p. 113), Capital Adequacy Ratio (CAR) is highly dependent on:

- Types of assets and the amount of risk attached to them, including assets listed in the balance sheet and administrative assets (not listed in the balance sheet). Each item in the asset is given a risk weight, the amount of which is based on the level of risk contained in the asset.

- Quality of assets or the level of collectability. In order to consider the quality of each asset in order to know how likely it is to receive the funds invested in the assets.

- The total assets of a bank, the greater the assets, the more the risk increases. So, a bank that has large assets does not guarantee the future of the bank, because the assets have their respective risk weights.

Credit Distribution. According to Teguh Pudjo Wilson (2008, p. 9), credit is: "The ability to carry out a purchase or enter into a loan with a promise of payment will be made in an agreed period." Understanding the credit on which credit is based in Indonesia is listed in the law the principal issue No.10 (1998: 4) is as follows: Credit is the provision of money or bills that can be likened to it, based on a loan agreement or agreement - borrowing between good parties and other parties requiring the borrower to repay the debt after a certain period of time with the amount, reward or profit sharing. From the definitions above, some conclusions can be drawn, namely:

1). The existence of a handover of money or can also be goods that give rise to bills to others, and by giving this loan, it is good to expect to obtain additional value from the loan product, in the form of interest as income for the bank concerned.

2 ). The credit process is based on an agreement that is mutual trust between the two parties to fulfill their respective obligations.

3 ). In this credit agreement, there is a joint agreement in repayment of debt and interest in a certain period.

In every credit distribution, consideration and prudence are needed so that trust which is the main element in credit is truly realized so that the credit can be given on the target and guaranteed the credit channel in time. in accordance with the agreement, because the interest income from the loan provided is the backbone of the bank's income, as well as to guarantee the smooth return of the principal, it is only natural that the said loan provision requires a calculation in accordance with the principle of credit distribution.

The function of the government bank is to provide services to the government, business, and individuals. An important activity is to finance development projects aimed at stimulating new and developing industries, in the form of providing funds or providing credit.

After the credit application is received by the account officer, the prospective customer is asked to provide additional information that can explain the contents of various documents submitted to the bank. Credit checks and analysis are divided into three activities, namely:

(1) Credit investigation or investigation (Suyatno, 2009, p. 78)

(a) Interviews with credit applicants or debtors.

(b) Collection of data related to credit applications submitted by customers. This includes interbank information and blacklisting and bad credit lists.

(c) Examination of the truth of the matters raised by the customer and other information obtained.

(d) Preparation of reports on the results of the examinations that have been carried out.

(2) Analysis of the application. The analysis carried out includes a careful assessment of 5C and 7P on the character, ability, capital, collateral, conditions or prospects of the debtor's business, and an assessment of credit repayment sources that emphasize the debtor's income (Weli, 2011, p. 85). 
In addition, it also presents an evaluation of juridical aspects of credit that aims to protect banks from risks that may arise. The analysis must describe the overall relationship concept of the credit applicant, meaning, consideration of the entire transaction related to the applicant, whether it has been given, is currently underway, or that will be provided by the bank. In this process, the data is taken from the application, guarantee, and customer files.

(3) Making a memo from the analysis. Analysis and evaluation must be made in a complete, accurate and objective manner and contain matters relating to the applicant's business information and debtor credibility (Weli, 2011). Assessment of the feasibility of the number of credit applications with projects or business activities that will be financed is useful to avoid markup practices that are detrimental to the bank. If a credit request is recommended for approval, the loan officer must compile the structure and type of credit as well as the terms and conditions of the credit. If the loan application is refused, the loan officer must provide reasons for the refusal.

Utilization of Assets. Operational activity of a bank is seen in the balance sheet and balance sheet changes. The liability side shows the management strategies and activities related to the source of fund collection, while the asset side shows the management strategies and activities related to the fund collection place. The fundraising side (liabilities) usually includes collecting funds obtained from authorized capital, deposits, demand deposits and savings. The purpose of banking management is to provide short-term or long-term credit. For this purpose, passivation is a tool. The side of the use of funds (assets) includes cash, accounts at the central bank, short-term and long-term loans, and fixed assets. Bank asset management is management that deals with the allocation of funds into investment possibilities. Allocation of funds into investment needs to be planned, organized, directed and supervised so that the objectives can be achieved.

In reality, the decision-making process in bank asset management is influenced by several factors, as follows:

- Bank and customer relationships. The bank receives the trust (trust) from its customers in the form of funds deposits. The customer believes that his banker will serve his needs and protect the funds he keeps. This unique relationship is what causes the bank and customer relationship as a "trustful relationship".

- The Pesaro. It is the people who have entered and entrusted their capital to the bank by expecting profits that are: (a). according to the investment risk, (b). balanced with profits derived from other alternative investments that are worth the risk. If not, they will choose other investment alternatives.

- Laws and Regulations. The funds collected must be managed in accordance with the provisions in the laws and regulations of the Central Bank, because they cannot manage the public money. Each bank is trusted by the community as a financial institution that will carry out business ethics consistently. The necessity of banking business to follow, implement and enforce positive law is a necessity that must not be ignored because positive law needs to be considered as a mere or "known factor" meaning it cannot be negotiated.

- Moral Appeal. It is a method to persuade and encourage bankers and traders to follow policies that the central bank believes are the interests of the development of all people. Although the policy may have high moral strength, everything depends on the strategies and decisions of the bankers and traders.

- Competition. When attention and consideration are directed towards bank relations and Misbah, stockholders, laws and regulations, and moral appeal from the central bank. The position of the banking business will be critical if the dynamics in the banking market, especially the money market, and the capital market, cause it to become an object rather than a subject. 
Conceptual framework. In general, banks in Indonesia face problems related to the number of nonperforming loans, liquidity, namely the problem of the high mobility of public funds so that banks must stimulate such high-interest rates so that public funds are reassembled and capital problems.

The role of banks is very helpful in providing capital in the form of credit because it is not possible to finance a project, both large and small, only supported by their own capital. The Bank is one of the government co-workers who is required to participate in the success of national development to finance economic development projects through investment financing in the investment of resources or working capital of the company.

The decision to grant credit depends on the main function of the Bank in question because each Bank has a different main function as stated in its articles of association. To achieve this goal the bank must be careful in providing credit assistance. However, this lending activity contains the highest level of risk, to avoid or to minimize credit risk that occurs, the Bank must conduct a careful assessment based on the Bank's technical requirements.

To determine whether a credit application can be accepted or not, according to the Indonesian banking development institution there are five factors that must be considered that are better known as the formula 7C; Character, Capital, Capacity, Collateral, Condition of economy, Constraint, and Covering. The link between credit distribution and asset utilization to the adequacy of capital can be described as follows:

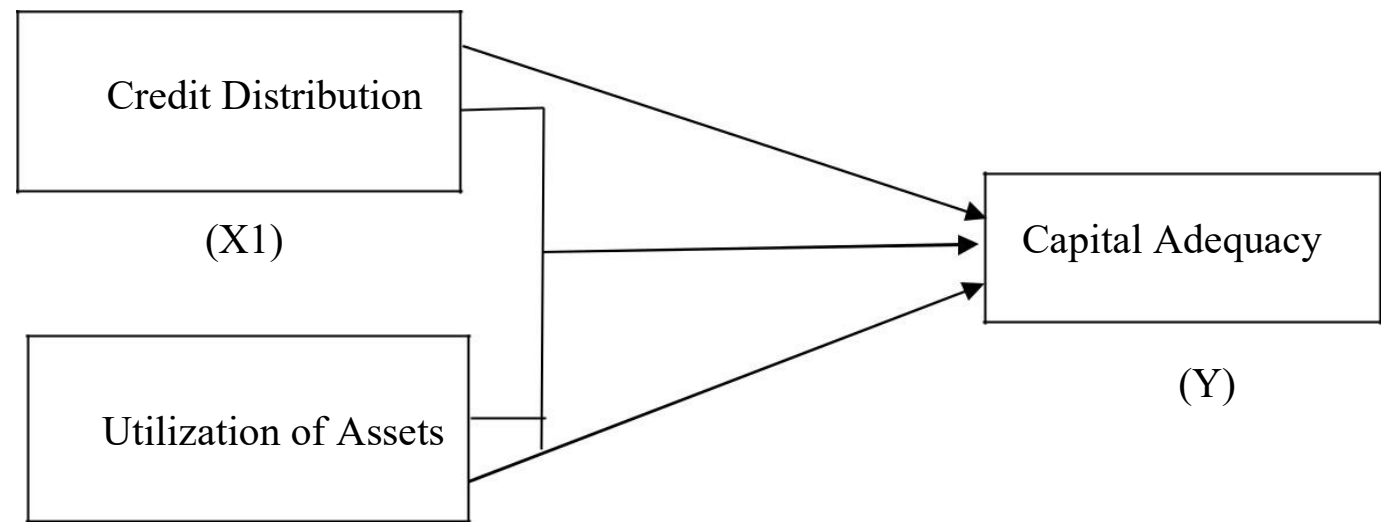

(X2)

Picture Conceptual Framework

Based on the conceptual framework described earlier, the research hypothesis can be formulated as follows:

- There is an effect of lending to the adequacy of capital at PT. North Sumatra Bank Branch Iskandar Muda Medan.

- There is an effect of asset utilization on the adequacy of capital at PT. North Sumatra Bank Branch Iskandar Muda Medan

- There is the influence of lending and asset utilization simultaneously to the adequacy of capital at PT. North Sumatra Bank Branch Iskandar Muda Medan.

\section{Research Methodology}

In this study, researchers conducted research using a research approach that is the associative approach. Associative research is a research that aims to determine the relationship between two or 
more variables that can be built into a theory which can function to explain, predict and control a symptom. (Sugiyono, 2012, p. 11).

This research was carried out at PT. North Sumatra Bank Iskandar Muda Branch N0 49 Middle Separation - Medan which is a financial institution and is engaged in financial savings and loan services for the general public. The research time is planned for December 2016 until March 2017. The data analysis technique used in this research is quantitative data analysis, which is testing and analyzing the data by calculating the numbers and then drawing conclusions from the test, with the formulas below.

Regression analysis is used to determine the effect of independent variables on the dependent variable. The regression equation in this study is as follows:

$\mathrm{Y}=\beta+\beta 1 \mathrm{x} 1+\beta 2 \times 2+\mathrm{e}$

The classical assumption of multiple regression test aims to analyze whether the regression model used in the study is a good model, then the data analyzed is feasible to be used as a knowledge recommendation or for practical problem-solving purposes. The classic assumption test used is a normality test, multi coloniality test, and heteroscedasticity test.

Statistical test $\mathrm{t}$ is done to test whether the independent variable $(\mathrm{X})$ individually has a significant or no relationship to the dependent variable (Y). To test the significance of the effect, a statistical test formula $t$.

The F test is used to test hypotheses that are simultaneous (together). Especially the significant testing of the double correlation coefficient. The proof is done by comparing the $\mathrm{F}$ table value with $\mathrm{F}$ count. $\mathrm{HO}$ is accepted if Ftable $>$ Founts for $\alpha=5 \%$, it means simultaneously the hypothesis is rejected, meaning that there is no influence of lending and simultaneous utilization of assets on the adequacy of capital at PT. North Sumatra Bank Branch Iskandar Muda Medan. Ha is accepted if Ftable $<$ F counts for $\alpha=5 \%$, it means that simultaneously the hypothesis is accepted, it means that there is influence of lending and simultaneous utilization of assets on the adequacy of capital at PT. North Sumatra Bank Branch Iskandar Muda Medan.

\section{Result and Discussion}

Data analysis was carried out with the help of the SPSS version 16 program where data input must be carried out, namely credit distribution and asset utilization on the adequacy of capital. After the data input is done, then a descriptive data analysis is performed regarding the condition of each research variable. Descriptive statistics are used to provide an overview or descriptive of a data that is seen from the mean (mean), minimum value, maximum value, and standard deviation.

Table 1. Descriptive Statistics Results

\begin{tabular}{|l|r|c|r|r|r|}
\hline & $\mathrm{N}$ & Minimum & Maximum & Mean & Std. Deviation \\
\hline Credit & & 114070215602.4 & 368644626990 & 154697196105.0 & 74825396297.26 \\
& 36 & 7 & 57 & 661 & 297 \\
Distribution & 36 & 209487948705.9 & 784573541512. & 304463367532.7 & 157782855836.1 \\
& 7 & 16 & 268 & 2943 \\
Utilization of & 36 & 13377470556.36 & 52318570558.0 & 20724523775.57 & 9624224041.246 \\
Assets & 36 & & 3 & 44 & 77 \\
Capital Adequacy & & & & & \\
Valid N (listwise) & & & & & \\
\hline
\end{tabular}

Source: Processed Data, 2017 
To find out the results of hypothesis testing related to the effect of lending and asset utilization on the adequacy of capital can be seen in the following table.

Table 2. Multiple linear regression coefficients

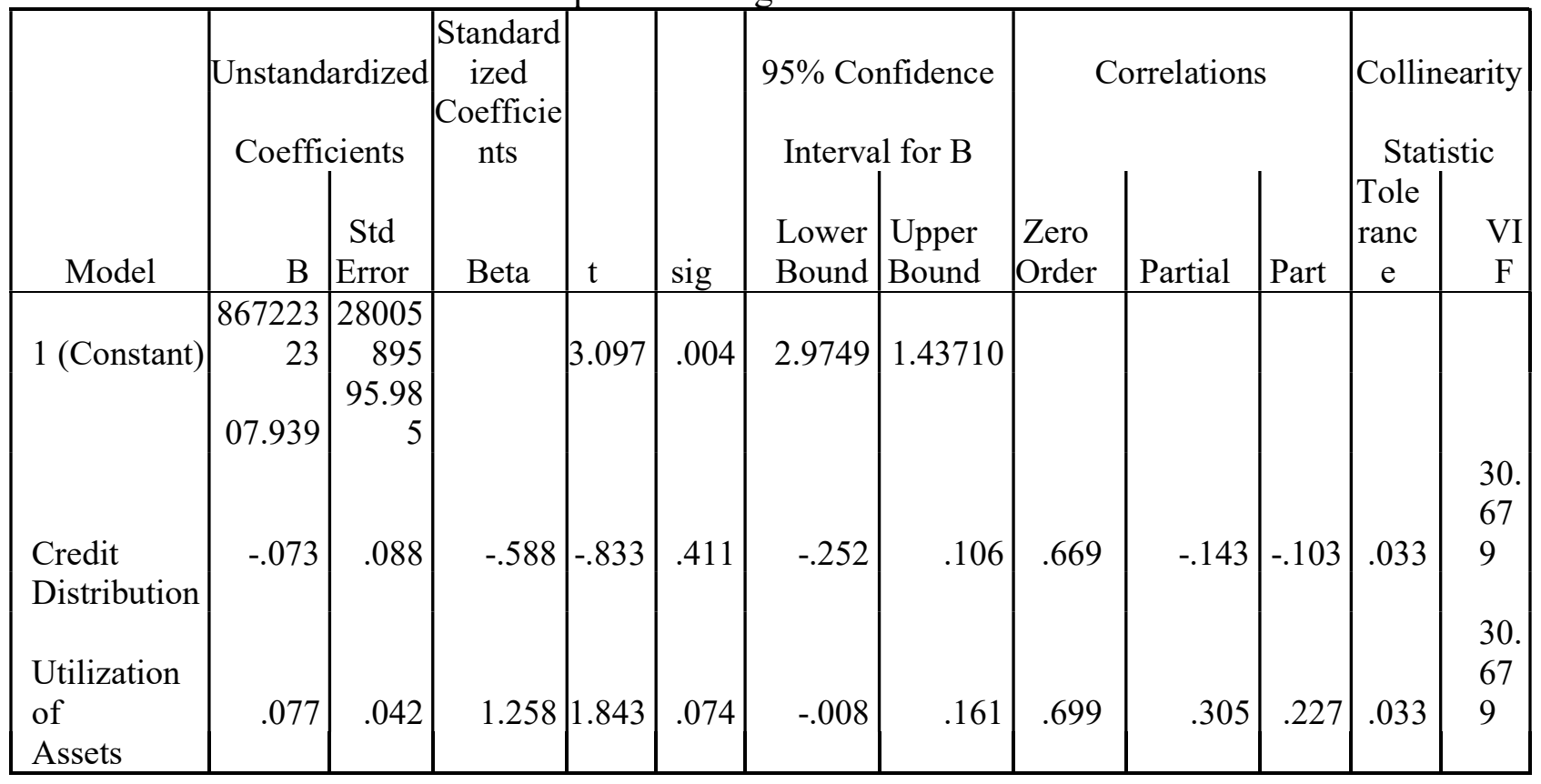

The coefficient for the regression equation of this study, which can be arranged in mathematical equations as follows:

$$
\begin{aligned}
& \mathrm{Y}=\mathrm{a}+\mathrm{b} 1 \mathrm{X} 1+\mathrm{b} 2 \mathrm{X} 2+\mathrm{e} \\
& \mathrm{Y}=867223207.939-0.073 \mathrm{X} 1+0.077 \mathrm{X} 2
\end{aligned}
$$

The multiple linear regression equation shows the value of $\mathrm{a}=867223207,939$ which means that if the independent variables do not exist then the company's capital adequacy is worth Rp. $867,223,207,939$, with a value of $\beta 1=-0,073 \mathrm{X} 1$ indicating that if credit distribution increases by 1 unit, it will reduce the adequacy of capital by $7.3 \%$. Besides that, it also shows the value of $\beta 2=$ $0.077 \mathrm{X} 2$ indicating that if the asset utilization increases by 1 unit then it will increase the adequacy of capital value by $7.7 \%$.

The t-test basically shows how much influence an explanatory or individual variable is independent in explaining the variation of the dependent variable. The price of $t$ arithmetic is then compared with the price of $\mathrm{t}$ table. For errors of $5 \%$ test of two parties and do $=\mathrm{n}-2=34$, then obtained table $=$ 2.042. The variable for lending value of $t$ counts $-0.833<\mathrm{t}$ table 2.042 means that Ho is accepted, and $\mathrm{Ha}$ is rejected, and it can be concluded that the variable lending partially does not affect the adequacy of capital. For asset utilization variables, the value of $t$ counts is $1.843<\mathrm{t}$ table 2.042 then Ho is accepted, and $\mathrm{Ha}$ is rejected. It can be concluded that the variable of asset utilization does not significantly influence the adequacy of capital.

The following is the result of the F-Test calculation. 
Table 3. ANOVA ${ }^{\mathrm{b}}$

\begin{tabular}{|c|c|r|c|c|c|}
\hline Model & Sum of Squares & df & Mean Square & F & Sig. \\
\hline \multirow{2}{*}{ Regression } & 1617633540294594500000. & & 808816770147297300000.00 & & .000 \\
& 1624265553569338400000. & 2 & 000 & & \\
Residual & 3241899093863933000000. & 33 & 49220168289979950000.000 & & \\
Total & & & & \\
\hline
\end{tabular}

a.Predictors:(Constant), Credit Distribution, Utilization of Assets

b.Dependent Variable : Capital Adequacy

The table shows that Fcount is 16.433 and the value of Ftable is 4.42 and these results indicate that Fcount $>\mathrm{F}$ table which means that together with the variables of lending and asset utilization in this study significantly influence the adequacy of capital.

Table below shows how much the quality of the regression model formed can explain the actual conditions, considering the value of the coefficient of determination (R squared).

Table 4. Results of the Determination Coefficient (Model Summary)

\begin{tabular}{|c|c|c|c|c|c|c|c|c|c|c|}
\hline \multirow[b]{2}{*}{$\begin{array}{l}\text { Mod } \\
\text { el }\end{array}$} & \multirow[b]{2}{*}{$\mathrm{R}$} & \multirow[b]{2}{*}{$\begin{array}{r}\mathrm{R} \\
\text { Squar } \\
\mathrm{e}\end{array}$} & \multirow[b]{2}{*}{$\begin{array}{r}\text { Adjuste } \\
\mathrm{d} \\
\mathrm{R} \\
\text { Square }\end{array}$} & \multirow[b]{2}{*}{$\begin{array}{c}\text { Std. Error of the } \\
\text { Estimate }\end{array}$} & \multicolumn{5}{|c|}{$\begin{array}{l}\text { Change } \\
\text { Statistics }\end{array}$} & \multirow[b]{2}{*}{$\begin{array}{l}\text { Durbin } \\
- \\
\text { Watso } \\
\mathrm{n}\end{array}$} \\
\hline & & & & & $\begin{array}{c}\mathrm{R} \\
\text { Square } \\
\text { Change } \\
\end{array}$ & $\begin{array}{c}\mathrm{F} \\
\text { Change } \\
\end{array}$ & df1 & $\mathrm{df} 2$ & $\begin{array}{l}\text { Sig. F } \\
\text { Change } \\
\end{array}$ & \\
\hline 1 & $.706^{\mathrm{a}}$ & .499 & .469 & $\begin{array}{c}7015708680.5240 \\
1\end{array}$ & .499 & 16.433 & 2 & 33 & .000 & .838 \\
\hline
\end{tabular}

a.Predictors:(Constant), Credit Distribution, Utilization of Assets

b.Dependent Variable: Capital Adequacy

The table shows the ability of the model in explaining the magnitude of the effect of independent variables (lending and asset utilization) on the dependent variable (the adequacy of capital) of 0.499 (49.9\%), of which $100 \%$ influences net income. to the amount of the adequacy of capital of $49.9 \%$ while the remaining $50.1 \%$ is influenced by other variables not examined in this study.

\section{Conclusion}

After analyzing the data and getting the research results and described in this discussion are as follows:

- Based on the results of the study, it is known that the answer to the problem formulation is that there is an influence of credit distribution and simultaneous use of assets on the adequacy of capital at PT. North Sumatra Bank Branch Iskandar Muda Medan.

- Based on testing the hypothesis with the $\mathrm{t}$-test is known for the variable lending value $\mathrm{t}$ count $-0.833<$ ttable 2.042 means that Ho is accepted, and Ha is rejected, and it can be concluded that the variable lending partially does not affect the adequacy of capital.

- Based on testing the hypothesis with t-test is known for asset utilization variables t count value $1.843<\mathrm{t}$ table 2.042 then Ho is accepted, and Ha is rejected, and it can be concluded that the variable of asset utilization does not significantly influence the adequacy of capital. 
- Based on testing the hypothesis with the F test, it is known that the Fcount value is 16.433 and the Ftable value is 4.42 and the results show that Fcount $>F$ table means that the variables of loan distribution and asset utilization together significantly influence the adequacy of capital.

- Based on the testing of the coefficient of determination by using a table of the summary model known the magnitude of the effect of independent variables (lending and asset utilization) on the dependent variable (the adequacy of capital) is 0.499 (49.9\%), while the remaining $50.1 \%$ is influenced by other variables not examined in this study.

Suggestions.

- Based on the results of the study shows there is an influence of credit distribution and utilization of assets simultaneously on capital adequacy at PT. The North Sumatra Branch of Iskandar Muda Medan Branch, the company should be able to increase the simultaneous application of lending and asset utilization in order to further increase the company's the adequacy of capital.

- Based on the results of the study there was no effect of partial lending on capital adequacy at PT. The North Sumatra Branch of Iskandar Muda Medan Branch, the company should be able to increase the application of credit disbursement so that in the management of credit and individual assets can separately provide support to increase the adequacy of the company's capital.

- Based on the results of the study there is no partial effect of asset utilization on the adequacy of capital at PT. North Sumatra Bank Branch Iskandar Muda Medan, companies should be able to increase the application of asset utilization so that in the management of credit and individual assets can separately provide support to increase the adequacy of the company's capital.

- Based on the results of the study together the variables of lending and asset utilization in this study significantly influence the adequacy of capital, the company should be able to increase lending and asset utilization simultaneously in order to provide a better influence on increasing the adequacy of capital of the company.

\section{References}

Abdullah (2012). Fundamentals of Financial Management. Second Edition. Publisher: ANDI, Bandung.

Arif Pratisto, (2009), Easy Entering Statistics with SPSS 17, Publisher Elex Media Komputindo, Jakarta.

Azuar Juliandi, Irfan and Saprinal Manurung (2014). Research Methodology, Complete, Practical and Easy to Understand. First Print, Publisher UMSU Press, Medan.

Cyndi Adelya and Hotma Jafar (2009) Effect of Third Party Funds on Credit Distribution, E-Journal Accounting Udayana University 7.1 (2009): 192-206.

Harahap, Sofyan Syafri (2005). Contemporary Audit. First Print. Jakarta: Erlangga Publisher.

Harahap, Winda (2015). The effect of loans, liquidity and capital adequacy on profitability at BRI

Medan Petisah Market Unit. Publisher: Faculty of Economics - University of Dharmaangsa, Medan.

Imam Ghozali (2009). Application, Multivariate Analysis with SPSS Program. Fourth Print. Publisher: Diponegoro University Publishing Agency, Semarang

Kamarudin Ahmad (2006). Corporate Financial Management, New Edition. Publisher PT. RajaGrafindo Persada, Jakarta.

Kasmir (2009). Banks and Other Financial Institutions, Sixth Edition, Publishers of Raja Grafindo Persada, Jakarta. 
Moh. Arman, Wayan Cipta (2015). Influence of Capital Adequacy and Credit Distribution Rate on Profit at Village Credit Institutions. Faculty of Economics - Gajah Mada University, Yogyakarta.

R. Siamat (2009). Corporate Management Application, Case Analysis, and Solution, Issue 2, Publisher of Mitra Wacana Media, Jakarta.

Sugiyono, (2012). Business Research Methods. Ninth Edition. Alfabeta publisher, Yogyakarta.

Teguh Pudjo Wilson (2008). Encyclopedia of Financial and Banking Economics. Erlangga Publisher. Jakarta.

Vinny Gita Risha (2011). The Influence of Loans, Liquidity and Capital Adequacy on Profitability (Companies on the IDX). Faculty of Economics - Gajah Mada University, Yogyakarta.

Weli, (2011). Operations Management, Second Edition, Graha Ilmu Publisher, Bandung. Weston and Brigham (2014). Financial Statement Analysis, Analysis of Financial Statements. Issue 8, Buku 2. Jakarta: Salemba Empat. 